\title{
Speech Acts Found in English Tourism Slogans Used in Indonesia
}

\author{
Giyatmi \\ Pendidikan Bahasa Inggris Universitas Veteran Bangun Nusantara \\ giyatmi85jimmy@gmail.com
}

Purwani Indri Astuti

Pendidikan Bahasa Inggris Universitas Veteran Bangun Nusantara

\section{Ratih Wijayava}

Pendidikan Bahasa Inggris Universitas Veteran Bangun Nusantara DOI: https://doi.org/10.18326/jopr.v3i1.70-85

Copyright (C) The Author (s)

This work is licensed under a Creative Commons Attribution-ShareAlike 4.0 International License. How to Cite: Giyatmi, Adtuti P., \& Wijayava R. (2021). Speech Acts Found in English Tourism Slogans Used in Indonesia. Journal of Pragmatics Research, 3(1). doi: https://doi.org/10.18326/jopr.v3i1.70-85

SUBMISSION
TRACK:
Received:
23-11-2020
Final Revision:
04-03-2021
Available online:
01-04-2021
Corresponding
Author:
Giyatmi
giyatmi85jimmy@gmail.
$\underline{\text { com }}$

\begin{abstract}
The research aims at describing the types and functions of speech acts in the tourism slogan in Indonesia. There has already been much research on tourism slogan, but only a few studies focusing on linguistics. To broaden the study of tourism slogan from linguistics perspective, the research focuses on the speech acts in the tourism slogans. It belongs to descriptive qualitative research by focusing on the phenomena of tourism slogans in society. The data of the research are tourism slogans of some cities in Indonesia found on the internet. The technique of data collection used is content analysis. The technique of data analysis consists of data reduction, data display, and verification. There is no data reduction in this research. Data is displayed in the table and the last step data is analyzed based on the problem statements. The researchers found 31 data of tourism slogans. There are 4 types of speech acts in tourism slogans namely representative speech acts (13 data), directive speech acts ( 7 data), commissive speech acts ( 3 data), and expressive speech acts $(8$ data). The researchers find 3 functions of speech acts in the tourism slogan such as giving information about the history of the city, nickname of the city, hope or idea of the city (19 data), asking (7 data), and promising ( 5 data). The findings show that there is a tendency to be very simple in the slogans found. Besides, the slogans come with an exclusive appeal by emphasizing the effective component in the message..
\end{abstract}

Keywords: tourism, slogans, speech acts. 
Website: http://e-journal.iainsalatiga.ac.id/index.php/jopr/index

\section{INTRODUCTION}

Indonesia is known as an archipelago country with more than 17,000 islands in South East Asia. Besides, Indonesia is blessed with various natural resources. Furthermore, having many islands makes Indonesia rich in cultural resources as well like languages, dances, customs, and traditional clothes. Both the natural and cultural resources can give benefits to the Indonesian government if they are well managed. One of them is by empowering the tourism potency of the island (Setiawan, 2015).

Even though all the management of tourism in Indonesia is under the ministry of culture and tourism in Jakarta, the government allows the local governments to manage their tourism potency. Based on the Central Statistics Agency (Biro Pusat Statistic), there are only twelve provinces in Indonesia that are visited by domestic and foreign tourists. Those provinces are Bali, West Java, Central Java, East Java, DKI Jakarta, West Sumatera, Lampung, South Sulawesi, South Sumatera, Banten, and North Sumatera .Whereas, there are still many other provinces especially East Indonesian provinces with their cultural and tourism potency that can be introduced to attract a great number of domestic and foreign tourists (RH, 2011). There are many marvelous tourism resorts in East Indonesian Provinces such as West Papua with Raja Ampat, South East Sulawesi with Wakatobi Island. The provinces blessed with the exotic natural beauty hopefully can give contribution for the national income. It becomes a new challenge for the local government to promote and market their tourism potency (Setiawan, 2015)

One way to promote the tourism potency is by creating tourism slogan dealing with a city or a province. The main objective of tourism image design is to raise tourists' knowledge of the destination, to enhance local tourism's competition, and to encourage regional tourism expansion (Chen\&Zhu,2016). Huadhom\&Trakulkasemsuk (2017) write that tourism slogan is a verbal media used in transforming meaningful message so that in advance it can persuade the tourists to visit certain tourist destination. Tourism slogan can be used to create national branding (Gali, Camprubi \& Donaire, 2016). It happens the same way of tourism slogan of a city. Creating a tourism slogan of a city hopefully can create the city branding so that it can attract tourists to visit the city. Promoting local tourism is as important as promoting national tourism. Tourism slogans have an important role in promoting it. Tourism slogan can be an effective way to promote tourist destinations and enable the consumers to receive and remember the information of it (Huang\&Lin,2017). One of tourism slogans used successfully in tourism marketing is the slogan of New York, namely I Love New York in 1970. After that many tourist destinations tried to create such kind of slogans to attract public interest (Huang\&Lin,2017) 
Some of us perhaps are familiar with Solo the Spirit of Java, Enjoy Jakarta, Jogjakarta Never Ending Asia. They are examples of tourism slogans of some cities in Indonesia. These tourism slogans hopefully can be a brand image for the city or province, so that the slogan must be informative, memorable, and marketable. There are still many other slogans such as Bali Simply the World's Best Island, Sparkling Surabaya, Semarang the Amazing Java, however, only few people know about those slogans.

Slogan usually uses text form in the marketing and advertising (Doyle in Huang\&Lin, 2017). Slogan is a memorable word, phrase or sentence used to advertise a person, a group, a product (Alsari \& Rosa, 2013). Supphellen and Nygaardsvik in (Huang\&Lin,2017) mention that slogan is short phrases that communicate descriptive and persuasive information

Huadhom\&Trakulkasemsuk (2017) conclude that slogan is a kind of ads that can be phrases or short sentence (in syntactic form) and functions to convey the identity, image and goodness of a certain company, product, service and organization to the consumers. In short we can say that a slogan is one of language phenomena since a slogan uses language (words, phrases, and sentences) as its media.

In addition, a slogan can be used as a means of communication because a slogan carries message for the readers or listeners or consumers. As a means of communication involving the speaker (the slogan maker), the listener and the messages, a slogan can be a form of speech act.

Speech act is introduced firstly by Austin. Actions performed via utterances are generally called speech acts (Yule,1996). Speech act belongs to pragmatics study in which there is particular intentional purpose beyond what the speakers say through their words, phrases, and sentences (Hidayat, 2016). An utterance with speaker's intention which can give effect on the listener is a speech act (Laosrirattanachai \& Panyametheekul, 2018). (Alkitri, 2011) writes that speech act happens when the speakers try to achieve their intended actions through a language and when the listeners try to deduce the intentional meaning of the speakers. There is an action that can be performed through an utterance in slogan. A slogan can be used to ask someone to do something, for example Enjoy Jakarta can be interpreted as requesting people to visit and enjoy Jakarta.

A slogan, as a speech act, consists of locution, illocution, and perlocution level. Austin in (Chiluwa, 2007) defines three kinds of act in an utterance. First is the locutionary act that is defined as the act of saying utterance using the grammar, phonology and semantics of the language, second is the illocutionary act that is defined as the intended meaning of certain utterance such as promise, command, criticism, greeting, declaration, and so on, third is the perlocutionary acts which happen when the utterance said achieves certain feedback or effect such as embarrassment, fear, confusion, enjoyment, or amusement. The locutionary act is the act of saying something, the illocution act is the act of doing something, and the perlocutionary is the 
Website: http://e-journal.iainsalatiga.ac.id/index.php/jopr/index

act of affecting something (Wijana, 1996). Drid writes that the locutionary act refers to the literal meaning of the utterances expressed through lexico-grammatical component (Drid, 2018). Meanwhile, the illocutionary act is the performative level of the speakers' utterances with intended meaning. The illocutionary acts can be ordering, apologizing, naming, thanking, warning, etc. in which the term speech acts actually refer to them. The perlocutionary act refers to the utterances leaving on impact on the listeners. Enjoy Jakarta is in the locution level when it is only said or written without any intention. However, Enjoy Jakarta with requesting meaning shows that the slogan is in illocution level. It is in the perlocution level when Enjoy Jakarta can give effect to the listener (the society) so that many locals and foreigner tourists visiting Jakarta.

Speech acts can be classified into five, i.e. declarative, representative, expressive, directive and commissive Yule (1996), Searle in (Laosrirattanachai \& Panyametheekul, 2018). Declarations are those kinds of speech acts that change the world via their utterance (Yule,1996). In this speech act, the speakers' utterances change the world or the situation through the words they use in their utterances. Searle in (Laosrirattanachai \& Panyametheekul, 2018) defines that declaration is utterances with formal state giving expeditious impact. The speakers must have a particular role, be in a particular context so that they can perform a declaration appropriately. For example $I$ now pronounce you husband and wife. The declaration of husband and wife in a marriage ceremony can only be appropriate if it is spoken by the priest. (Wardani, 2018) mentions that declaring, baptizing, firing from employment, hiring, and also asserting belong to declaration speech act.

Representatives or assertive are those kinds of speech of speech acts stating what the speaker believe to be the case or not (Yule, 1996). Searle in (Laosrirattanachai \& Panyametheekul, 2018) defines representative speech act happens when the speakers utterances is the truth of the world around the speakers. In this speech act, the speakers use the words in their utterances that fit the world (of belief). There are some examples of representative speech acts such as statement of fact, conclusion, description, and assertion. The example of representative is It is a bright day. The speaker describes the day as a bright day based on the situation in that day. Asserting, stating, concluding, boasting, describing, and suggesting belong to representative speech acts (Wardani,2018).

Expressive are those kinds of speech acts that state what the speaker feels. The speaker makes the words they use in utterances fit the world (of feeling). Searle in (Laosrirattanachai \& Panyametheekul, 2018) states that when the speakers express the utterance relating to the psychological condition refers to expressive speech acts. Statement of pleasure, pain, likes, dislikes, joy or sorrow are included in expressive speech act. The utterance with expressive speech 
act is Congratulation! This expression states the happiness of the speaker for someone's success. Expressive speech acts relate to some expression with some psychological states such as greeting, thanking, apologizing, complaining, and congratulation (Wardani, 2018).

Directives are those kinds of speech acts that speakers use to get someone else to do something (Yule,1996). Searl in (Laosrirattanachai \& Panyametheekul, 2018) states that directive speech act happens when the speakers' utterance tries to get the listeners do something. In this case, the speaker wants someone to do some actions. Those expressions can be as order, request, command and suggestion such as Give me a cup of tea. (Wardani, 2018) mentions some expressions that belong to directive speech acts such as requesting, advising, commanding, challenging, inviting, daring, and entreating.

Commissives are those kinds of speech acts that speakers use to commit themselves to future action. They express what the speaker intends. Searle in (Laosrirattanachai \& Panyametheekul, 2018) writes that commissive speech act happens when the speakers' utterances deal with an action in the future. (Wardani, 2018) writes that expressive speech acts can be seen in the form of promising, pledging, threatening, vowing, and offering.

The writers feel interested to analyze the tourism slogans found in Indonesia from linguistics perspective. The research aims at describing types of speech acts and its function found in the English tourism slogans used in Indonesia. There have already been studies on tourism slogans, however, most of them focus on business, marketing, and advertising and only few focus on linguistics (Hudhom\&Trakulkasemsuk, 2017)

The studies are (1) Papp-Vary in 2010 has a research on slogans with logo, a combination of verbal and visual communication techniques in branding country tourism, (2) Pike in 2004 has a study on destination branding position slogans based on the key terms used in each slogans (Huadhom\&Trakulkasemsuk, 2017). In addition, Papp-Vary et.al (2018) find out that the classification of tourism slogan of countries includes the name of the country, geographical units, the use of the word Discover, Beautiful, wonderful, nature, and happiness.

There are some examples of studies of tourism slogans focusing on linguistics. Khan in 2014 studies tourism slogans to identify the most used theme as art marketing through word play in tourism slogans (Khan,2014). Huadhom and Trakulkasemsuk in 2017 have a research on tourism slogans focusing in linguistics especially in the syntactic features of tourism slogans. This study emphasizes on the syntactic structures in 100 tourism slogans found in online media. Based on the finding, it can be seen that Noun Phrase are the most dominant used in tourism slogans then simple declarative sentence. The most dominant form of NP is adjective (modifier) and a noun (head). Meanwhile the most common sentence is declarative sentence which is used to make a statement (Huadhom \&Trakulkasemsuk,2017). In addition Malenkina and Ivanov in 2018 have a 
Website: http://e-journal.iainsalatiga.ac.id/index.php/jopr/index

research on the official tourism websites of the seventeen Spanish Autonomous Communities for destination management, marketing as well as branding to find the linguistic strategies used (Malenkina \& Ivanov, 2018). The research shows that the target tourism discourse is used inform the tourist but the main function is to persuade them, thus need to maximize the language in the tourism promotion. Another study done by Gali, Camprubi and Donaire, in 2016 aims at examining the characteristics of 150 tourism destinations around the world in the level of national, regional and local (Gali, Camprubi \& Donaire, 2016). The findings show that there is a tendency to be very simple in the slogans found. Besides, the slogans come with an exclusive appeal by emphasizing the effective component in the message. To broaden the study of tourism slogan from linguistics perspective, the research focuses on the speech acts used in the tourism slogans

\section{RESEARCH METHOD}

This research belongs to a qualitative research since this research describes the phenomena of the use of English in Indonesian tourism slogans. The data are the tourism slogans in some websites on the internet especially those deal with tourism slogan such as https://travel.kompas.com/read/2017/06/15/040500927/arti.di.balik.logo.baru.10.daerah.wisata.di.i ndonesia?page=all, $\quad$ https://www.goodnewsfromindonesia.id/2017/06/17/inilah-logo-baru-10destinasi-wisata-indonesia, $\quad$ http://official-irfan.blogspot.com/2010/06/slogan-untuk-promosipariwisata.html . The data are only the tourism slogans using English, so the writers do not use the tourism slogan in Indonesian. The writers feel interested to analyze the tourism slogans found in Indonesia from linguistics perspective. The research aims at describing types of speech acts and its function found in the English tourism slogans used in Indonesia. The technique of data collecting used in this research is content analysis. After that the researchers classified the data found based on the lingual form of the tourism slogan, the researchers analyze the slogans deeply dealing with the content of the tourism slogans found in the internet. The technique of data analysis consists of data reduction, data display, and verification. The writers do not reduce the data during the research. Then the data are displayed in the table and described in narration. After that, the data are verified. To verify the data, the researchers use theory triangulation.

\section{RESULTS \&DISCUSSION}

\section{Types of Speech Act used in Tourism Slogans}

The writer found 31 data of English tourism slogan. The data are classified based on types of speech acts. The classification can be seen in the following table; 
Table 6.1.Types of Speech Acts in Tourism Slogans

\begin{tabular}{clcc}
\hline No & & Types of Speech acts & Numbers \\
1 & Representative & 13 \\
2 & Directive & 7 \\
3 & Commissive & & 3 \\
4 & Expressive & Total & 8 \\
& & Tol & 31 \\
\hline
\end{tabular}

Based on the table it can be seen that there are four kinds of speech acts that can be found in the English tourism slogan used in Indonesia. They are representative, directive, commissive and expressive.

Representative speech acts

The representative slogan used in this slogan deals with the description and fact about the cities, provinces, and islands using the slogan. There are 13 data classified into representative speech acts. The examples of representative slogans that have been found are; Solo the spirit of Java, Pontianak: The City of Equator, Palembang the City Where Culture and River meet in Harmony.

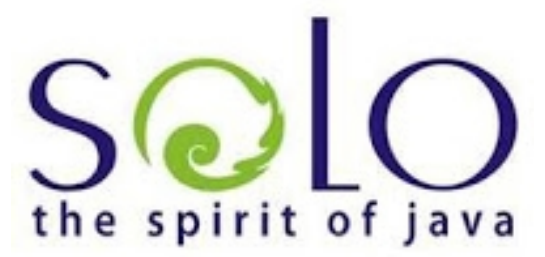

Figure 6.2. Logo of Solo

Literally Solo the spirit of Java means that Solo becomes the spirit or the soul of Java. Solo is a small city in Central Java. However, Solo, has a big influence in the development of Javanese culture. There are two famous palaces in Solo, namely Kasunanan Palace and Mangkunegaran Palace. Besides, there are many traditions that are still kept up to now such as the celebration of Sekaten (The celebration of Prophet Muhammad's SAW birth in Javanese culture), celebration of 1st Muharam (The celebration of Islamic New Year). Those things lead Solo as the spirit of Java.

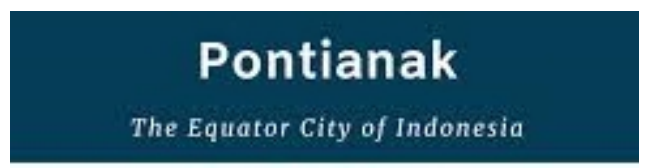

Figure 6.3. Logo of Pontianak

Pontianak: The Equator City of Indonesia, the classification of the slogan into representative speech act is based on the fact that Pontianak is the city of equator. Pontianak is the capital city of 
West Kalimantan Province. Pontianak is one of the cities in Indonesia where the equator line passes across it so that is why Pontianak is called the city of equator.

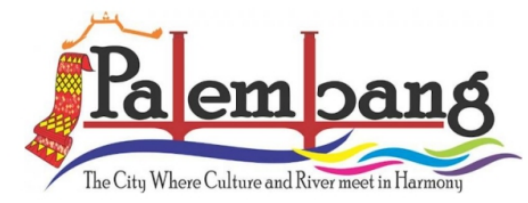

Figure 6.4. Logo of Palembang

The slogan says Palembang the City Where Culture and River meet in Harmony. Palembang as the capital city of South Sumatera is well-known for its Musi River (Sungai Musi). The $750 \mathrm{~km}$ length river divides Palembang into two, namely Seberang Ilir and Seberang Ulu. Musi River is also known as Batanghari Sembilan (Nine Rivers). The Musi River in Palembang is the estuary of several rivers such as the Komering River, Ongan River, Lematang River, and Rawas River. There is a famous iconic bridge called Ampera Bridge above it. This river has been the main transportation since the Kingdom of Srivijaya time up to nowadays.

Palembang is not directly adjacent to the sea, however, the streams in this city enable the merchants' ships from Tionghoa and Middle East to come several areas in the city easily. The trading activity contributes to the cultural acculturation of the merchants from Tionghoa and Middle East with the local people (Melayu people). Palembang has become a melting pot of Melayu culture, Tionghoa culture and Middle East Culture.

Directive speech acts

It deals with asking someone to do something. The writers found 7 slogans belonging to directive speech act. Those slogans belong to directive speech acts because the slogans' ends are to ask the readers to do what the slogans say. The slogans use imperative sentence to show the directive action. Most the slogans are started with Infinitive Verb such as Come, Explore, Enjoy, and Experience.

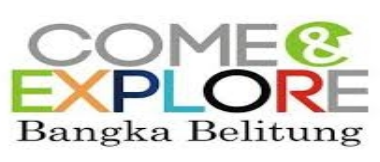

Figure 6.5. Logo of Bangka Belitung 
Come and Explore Bangka Belitung, this slogan asks the readers to come and explore Bangka Belitung. Bangka Belitung Islands are two small islands that previously belong to Palembang Province. Bangka Belitung Islands are famous for the beautiful beaches with granite stones. Besides, Bangka Belitung Islands are also well-known with their culinary. Even in 2008, there was a phenomenal film adapted from a best-seller novel entitles Laskar Pelangi (Rainbow Troops) made in Belitung Island. This movie can raise the popularity of this island.

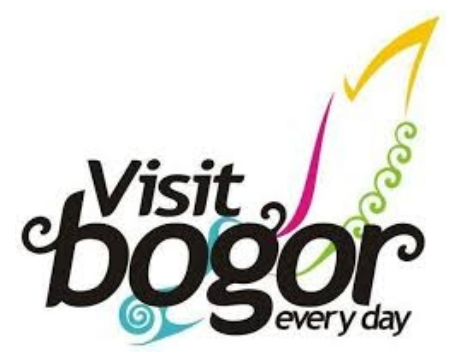

Figure 6.6. Logo of Bogor

This slogan requests the readers to visit Bogor every day. Bogor is a city belongs to West Java Province and it is known as Kota Hujan (City of Rain) for its high rainfall there. Bogor offers many tourism attractions such as Bogor Botanical Garden, (Kebun Raya Bogor), Bogor Presidential Palace (Istana Bogor), deer breeding centre (Pusat penangkaran Rusa). Besides, there is a famous natural tourism in Puncak. Puncak become a very busy tourist resort on weekdays and holiday.

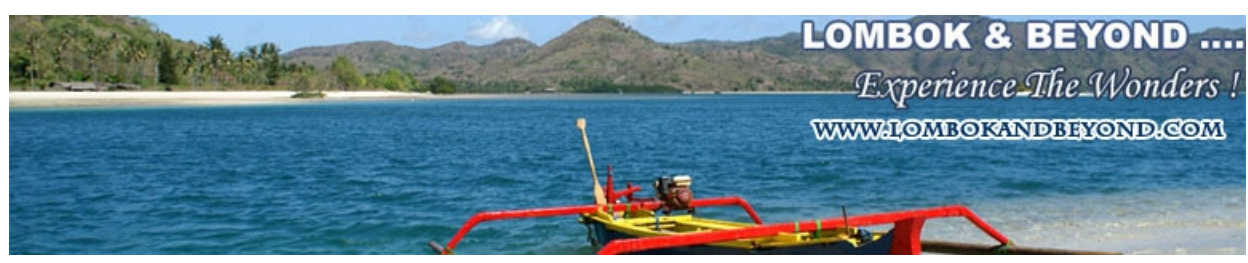

Figure 6.7. Logo of Lombok

Lombok: Experience the wonders, this slogan asks the readers to experience the wonders that can be found in Lombok. Lombok is an island in West Nusa Tenggara, Indonesia. Tourism is important income for Lombok. Lombok Island has many beautiful beaches such as Senggigi, Gili Trawangan. Lombok is also famous of Sasak Tribes. There is the second highest volcano in Indonesia, called Rinjani Mount. On top of it, there is a crater lake known as Segara Anak with water as blue as the sea water. Even, Lombok is predicted as the new Bali. Lombok has marvelous nature beauty and culture. Lombok has volcanoes, waterfall, coral garden, pristine beaches, plantations, festivals, temples, and an atmosphere similar to Bali 20 years ago (2019, August 15). 


\section{Commissive speech acts}

It deals with some commitment to the future. Commissive speech acts found in this research mostly deal with promises. There are 3 slogans classified into commissive speech acts, such as Banda Aceh the Spiritual Destination City, Padang Your Motherland and Jogjakarta Never Ending Asia.

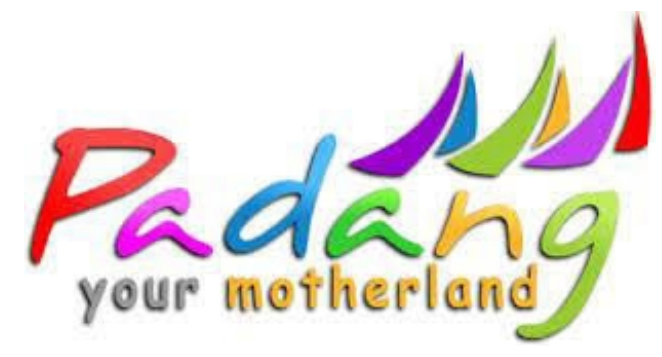

Figure 6.7. Logo of Padang

Padang, Your Motherland, this slogan promises that Padang will always be the motherland for everyone visiting it. Padang is the capital city of West Sumatra in Indonesia. Padang with its beauty, hospitality, and delicious food will give comfort for everyone staying there as if they are in their motherland.

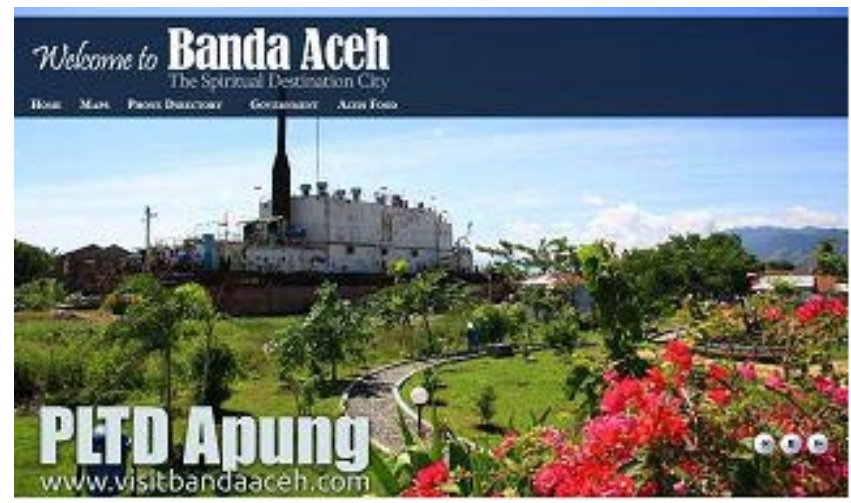

Figure 6.8. Logo of Aceh

Banda Aceh, The Spiritual Destination City. Banda Aceh is the capital city of Aceh (now Nangroe Aceh Darussalam) in Indonesia. Aceh Province itself is known as Serambi Mekah (The Veranda of Mecca), a name that is full of religious nuance, faith and devotion to Islam. Mecca is the holy city for Moslem people. Aceh is given that name for some reasons. Aceh was the first gateway where Islam came to Indonesia and Aceh was the terminal for all Indonesian Moslem 
who wanted to perform Haj in Mecca in the past time. Before performing their haj, they had to spend six months staying in Bandar Aceh Darusalam (the previous name of Banda Aceh capital city). Besides, there was the first Islamic Kingdom found in Aceh, called Samudra Pasai Kingdom (2020, Januari 19). So Aceh has been well-known for its spiritual nuance since the old time. Nowadays, Banda Aceh as the capital city of Nangroe Aceh Darussalam promises that it will become spiritual tourist destination for everyone.

\section{Expressive speech acts}

It deals with slogans used to express feeling about something. There are 8 slogans belonging to expressive speech acts such as The Sparkling Surabaya, Lampung: Exotic and Marvelous Adventure, Bali Simply the World's Best Island. Most of them have something to do with admiration on the certain place (town, province, and island).

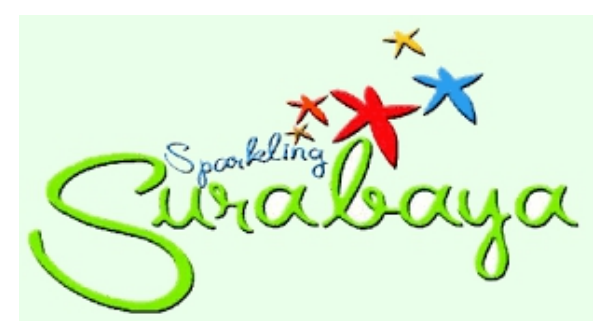

Figure 6.9. Logo of Surabaya

Sparkling Surabaya is a slogan belonging to Surabaya as the capital city of East Java in Indonesia. It is the second largest city in Indonesia after Jakarta. Surabaya government tries to create Surabaya as a comfort, safe and environmentally friendly city for everyone. Surabaya offers a clean and green modern city. As a modern city, Surabaya tries to provide complete public facilities so that everyone staying in Surabaya feels enjoyable. Besides, there are several city parks in the city so that everyone feels cool and comfort there. Those are several efforts to make Surabaya sparkling.

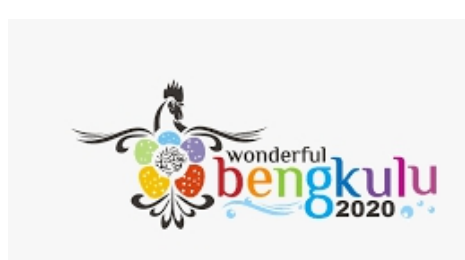

Figure 6.10. Logo of Bengkulu 
Wonderful Bengkulu 2020, the slogan is classified into expressive speech act because it consists of expression of admiration. Sumatra is one of islands in Indonesia. Sumatra consists of 10 provinces and one of them is Bengkulu. It is located in the southwest coast of Sumatra. Most people know that Sumatra is only about Saman Dance from Nangroe Aceh Darussalam, Toba Lake in North Sumatra, Gadang House in West Sumatra, Ampera Brigde in Musi River in Palembang South Sumatra, School for Elephants in Lampung. However, only few people Bengkulu, the other side of Sumatra. Apparently, there are some wonderful places in Bengkulu such as Panjang Beach, Isolation house for Ir. Soekarno (the 1st President of Indonesia), the Fortress of Marlborogh. There is a famous flower that becomes the icon of Bengkulu, i.e. Rafllesia Arnoldi. It is a species of flower in the parasitic genus Rafflesia Arnoldi which produces a very strong and horrible odor of decay flesh

\section{Functions of Speech Act used in Tourism Slogan}

There are three functions of English tourism slogan used in Indonesia such as:

Table 6.11. Functions of Speech Acts

\begin{tabular}{|c|c|c|}
\hline No & Function & Numbers \\
\hline 1 & Giving information (historical information, name, future dream, location) & 19 \\
\hline 2 & Asking & 7 \\
\hline 3 & Promising & 5 \\
\hline & Total & 31 \\
\hline
\end{tabular}

\section{Giving information}

The slogan may use as a media to give some information. The researchers found 19 data of slogan for giving information. Those data then can be classified based on the content of the information, such as; historical information, nickname, future dream,, and location.

Historical information can be found on the slogan from several towns such as Palembang the City Where Culture and River Meet in Harmony (Palembang), Makasar: Historic Port for Spices and Sailing Ships (Makasar), Colourful Medan (Medan), The Spirit of Java (Solo), Semarang: The Amazing of Java (Semarang), Sumenep The Soul of Madura, Wonosobo the Soul of Java. All the slogans give the readers information dealing with the history of the towns.

Makassar: Historic Port for Spices and Sailing Ships, this slogan is closely related to the historical fact about Makassar. Since the $14^{\text {th }}$ century Makassar, previously is known as Ujung Pandang was known as a busy sea port. Many merchants' ships from China, India sailed to Makassar for trading. In $16^{\text {th }}$ century Spanish and Portuguese made Makassar as their entrance port during their sailing to find Spice Island (https://awesome- 
indonesia.blogspot.com/2012/07/makassar-historic-port-for-spices-and.html). The use of the historical fact is to revive the greatness of the old time.

Some tourism slogans are used to give information about the nickname of several places (the city, town, province, and island), such as Pontianak: the Equator City of Indonesia and Pekalongan World's City of Batik. Both slogans indirectly refer to the nickname of the two cities. Pontianak is known as Kota Kathulistiwa (The City of Equator). Pontianak is situated in the 0 degree of North Latitude. There is a Katulistiwa Monument built in Siantan, the city in the north of Pontianak. This monument is one of the most visited tourism destinations in Pontianak. Meanwhile, Pekalongan has already been known as the city of Batik in Indonesia.

Hope and idea of a city also can be used in a slogan. It can be found in the slogan of several cities such as Sparkling Surabaya, Wonderful Riau, Majestic Banyuwangi, Stunning Bandung: Where the Wonders of West Java Begin, Bali Simply the World's Best Island, Magnificient Samarinda, Pangandaran Golden Visage, Wonderful Bengkulu, Pacitan the Paradise of Java and Lampung Exotic and Marvelous Adventure. The slogans are about the hopes and ideas that the city want to reach especially those that have something to do with tourism. For example, Bali Simply The World's Best Island, this slogan is closely related to the hope to make Bali as the best island in the world. The world has already recognized Bali for its nature beauty and its unique culture so that there are many tourists visiting Bali. However making Bali as the best island in the world hopefully can increase more tourists visiting Bali. Sparkling Surabaya aims at informing that Surabaya want to be a sparkling city to attract tourists' attention. To do so the government of Surabaya launched Sparkling Surabaya in 2006.

Asking

There are 7 data of slogans functioning to ask someone to do something. The slogans functioning for asking are Come and Explore Bangka Belitung, Enjoy Jakarta, Batam, Experience it, Lombok: Expereince the wonders, Banten: Come and Enjoy here, Visit Bogor Every day, Enjoy Ternate. All the slogans ask the audience to do something. It is reflected in the use of the verb used in the slogan such as experience, come, explore and visit.

Promising

Five tourism slogans function as promising. The Slogans are Banda Aceh: the Spiritual Destination City, Padang Your Motherland, Manado: The Land of Smiling People, Jogja Never Ending Asia, and Gorontalo: The Hidden Paradise. They give some promises or offer something to the visitors if they visit the city. The examples of the slogans functioning as promising are Manado: The Land of Smiling People and Gorontalo: The Hidden Paradise.

The slogan of Manado: The Land of Smiling People promises that Manado is the city where the friendly people with the beautiful smiling live in. It means that when the visitors visit Manado 
they will be very grateful because of its smiling people. Hopefully it can attract their visiting to Manado. Another example is Gorontalo: The Hidden Paradise. The slogans promise that by visiting Gorontalo, the visitors will find and enjoy the beauty of Gorontalo which is compared to that of paradise. Gorontalo is one of the cities in Sulawesi province which is very well-known for gorgeous beaches, marvelous sea park. Those are just like the hidden paradise especially for those who fond of diving and marine tourism.

\section{CONCLUSION}

Tourism slogan is one way that can be applied to introduce and promote the tourism potency belongs to a town or country. Hopefully, the domestic and foreign tourists will be eager to visit them. As one of the countries having many tourism attractions, having tourism slogan for each towns is very necessary.

As one of language phenomena, a slogan has several items to be analyzed from linguistics perspective such as its speech act. Having analyzed the tourism slogans found in Indonesia, the researchers concludes that (1) there are 4 types of speech acts used in tourism slogan, namely representative speech acts, directive speech acts, commissive speech acts, and expressive speech act, (2) There are 3 functions of speech acts used in tourism slogans, namely giving information dealing with the historical background, name, and hopes of certain town. The other functions are asking and promising. The researchers believe that this research is still away from being perfect, so hopefully there will be another research to complete it. Other researchers may have a research about tourism slogan that focuses on the figurative language used or they also can have a research on tourism slogans around the world such as Malaysia True the Asia, Japan Endless Discovery, Amazing Thailand, etc.

\section{REFERENCES}

Alkitri, S. (2011). Speech Act Analysis to Short Stories. Journal Of Language Teaching And Research, 2(6), 1374-1384.

Alsari, M., \& Rosa, R. (2013). Types Of Illocutionary Acts Used In Slogan Of Soft Drink Advertisements In Magazines. English Language And Literature, 1(2), 99-101. Retrieved from http://ejournal.unp.ac.id/index.php/ell/article/view/902/0

Chiluwa, I. (2007). A Speech Act Analysis of Written Adverts of Soft Drinks in Nigeria. Babcock Journal Of Mass Communication, 1(3). 
Chen, M., \& Zhu, M. (2016). Effect of Name of Region on Tourism Image Slogan. In International Conference on Judicial, Administrative and Humanitarian Problems of State Structures and Economical Subjects (JAHP 2016) (pp. 55-58). Atlantis Press.

Drid, T. (2018). Language as Action: Fundamentals of the Speech Act Theory. Praxis International Journal Of Social Science And Literature, 1(10).

Gali, N., Camprubi, R., \& Donaire, J. (2016). Analysing tourism slogans in top tourism destinations. Journal Of Destination Marketing \& Management.

Hidayat, A. (2016). Speech Acts: Force Behind Words. English Education: Jurnal Tadris Bahasa Inggris, 9(1), 1-12.

Hudhom, N., \& Trakulkasemsuk, W. (2017). Syntactic Analysis of Online Tourism Slogans: Frequency, Forms, and Functions. PASAA (53)

Khan, S. (2014). Word play in destination marketing: an analysis of country tourism slogans. TEAM Journal of Hospitality and Tourism, 11(1), 27-39

Laosrirattanachai, P., \& Panyametheekul, S. (2018). A Factor for Interpreting Tourism Slogan. JOURNAL OF LANGUAGE AND LINGUISTICS, 36(2).

Malenkina, N., \& Ivanov, S. (2018). A Linguistic Analysis of the Official Tourism Websites of the Seventeen Spanish Autonomous Communities. Journal Of Destination Marketing \& Management (Forthcoming). doi: https://doi.org/10.1016/j.jdmm.2018.01.007

RH, P. (Ed.). (2011, May 8). Time for N. Maluku to become tourist destination. Antaranew.Com. https://en.antaranews.com/news/71168/time-for-n-maluku-to-become-tourist-destination

Setiawan, I. (2015). Potensi Destinasi Wisata Di Indonesia Menuju Kemandirian Ekonomi. Proceeding SENDI_U. Retrieved from https://www.unisbank.ac.id/ojs/index.php/sendi_u/article/view/3321

Shu-Chun Lucy Huang \& Li-Pin Lynn Lin (2017): Awareness Effects of the Tourism Slogans of Ten Destinations in Asia.Journal of China Tourism Research. DOI:10.1080/19388160.2017.1399191

Vary, P. et.al. (2018). Discover your destination!" A classification of tourism slogans of countries around the world. Forum on Economics \& Business / Közgazdász Fórum, 21 (137),18-49

Wardani, W. (2018). Pragmatics Analysis Of English Slogans Used In Motorcycleadvertisement. International Journal Of English And Literature (IJEL), 8(3), 69-78.

Wijana, I. (1996). Dasar-dasar Pragmatik. Yogyakarta: Penerbit Andi.

Yule, G. (1996). Pragmatics. Oxford: Oxford University Press.

Lombok The New Bali: How Indonesia Will Make It Happen. (2019, August 15). Invest Islands. https://invest-islands.com/lombok-the-new-bali-indonesia/ 
Journal of Pragmatics Research

Vol. 03, No. 01 (2021), pp.70-85

E-ISSN: $2656-8020$

Website: http://e-journal.iainsalatiga.ac.id/index.php/jopr/index

Mengapa Aceh Dijuluki Kota Serambi Mekkah? (2020, January 19). Kompas.Com.

https://www.kompas.com/skola/read/2020/01/19/160000069/mengapa-aceh-dijuluki-kotaserambi-mekkah-

?page=all\#: :text $=$ Pada $\% 20$ awal $\% 20 \mathrm{abad} \% 20 \mathrm{ke} \% 2 \mathrm{D} 17$,begitu $\% 20 \mathrm{besar} \% 20$ dalam $\% 20 \mathrm{ke}$ hidupan $\% 20$ masyarakat.\&text $=$ Sehingga $\% 20$ pada $\% 20$ masa $\% 20 \mathrm{itu} \% 20$ Aceh,Mekkah $\% 22$ \%20(Serambi\%20Mekkah)

Makassar : Historic Port For Spices And Sailing Ships. (n.d.). Awesome Indonesia. Retrieved August 24, 2017, from https://awesome-indonesia.blogspot.com/2012/07/makassarhistoric-port-for-spices-and.html 